\title{
Prioritizing Factors Affecting the Implementation of a MICE Professional English Program
}

\author{
Hui-Wen Vivian Tang ${ }^{*}$, Kuopao Chang' ${ }^{2}$ Mu-Shang Yin ${ }^{3}$ \\ ${ }^{1}$ Teacher Education Center, Ming Chuan University, Taoyuan \\ ${ }^{2}$ Graduate School of Education, Ming Chuan University, Taoyuan \\ ${ }^{3}$ Department of Travel Management, Hsing Wu University, New Taipei City \\ Email: ${ }^{*}$ kshvt00@hotmail.com, kuopao@mail.mcu.edu.tw, yin max@hotmail.com
}

Received May 2014

\begin{abstract}
The study was designed to prioritize a plethora of factors that may affect or impede the success of implementing a MICE professional English program as an educational innovation at a tertiary context in Taiwan. Through the utilization of modified Delphi method and analytic hierarchy analysis (AHP), priorities were generated in a comprehensive format pertaining to the top five factors critical to successful implementation of the intended program. The study offers practical implementations by pointing to the importance of detecting highly prioritized factors. It was recommended that the intended group of implementers reduce the hindering factors and maximize the supportive ones for all engaged in the implementation process. The method introduced will help future researchers understand how ESP programs can be implemented effectively in other settings to achieve maximum impact. Several practical and research implications were discussed.
\end{abstract}

\section{Keywords}

MICE Industry, English for Specific Purposes, Program Implementation, Analytic Hierarchy Process, Delphi Panel

\section{Introduction}

The past decade has seen sustainable growth for the meeting, incentive, convention, and exhibition (MICE) industry in the form of hosting mega events and constructing massive centers in the Asia-Pacific region [1] [2]. The ongoing expansion on convention venues and numbers of exhibitions has brought with the challenge of adequately preparing workforce to enter this industry on the rise [1]. Aside from the continuous construction of convention properties and expansion of events held, this anticipated growth in MICE human resources is due to increasing globalization which translates into a need for more English-proficient workforce in the MICE industry.

Despite a general academic response to educational practices and research on human resource development in "Corresponding author. 
hospitality, international business and event management, there has been very little written on the topic of English for the MICE industry and much less on any professional training preparing English proficient employees before entering the MICE industry. Only one study was found targeting at developing a professional English competence training model for the MICE industry. Highly prioritized competences in the aforementioned two studies provided practical implications for planning and implementing a content-based and English-medium instruction curriculum focusing on the training of MICE English within an Applied English Department of a tertiary context in Taiwan [3]. As the convention industry grows, continued investigation into multifaceted issues involved in successful planning and implementations of training programs for MICE English professionals is essential to determine how to meet the human resource needs for internationalizing Taiwan's convention industry and to estimate the current capacities of applied English undergraduate programs to adopt an appropriate learning process for nurturing MICE English professionals. The present study is designed to identify priority factors affecting the success of implementing a MICE professional English program at an Applied English Department in Taiwan. Utilizing analytic hierarchy process (AHP) to estimate priority weights among interrelated factors, this study would have contributions to existing literature on prioritizing strategic decisions by specifying critical factors to focus on in order to ensure quality of and maximize success on program implementations.

\section{Literature Review}

\subsection{Factors Affecting Program Implementation}

The concept of educational program implementation has been documented by many scholars. To find a point of entry wherein program implementation studies can be initiated in the English for specific purposes (ESP) context of Taiwan, there is a necessity to look into previous implementation models that have been used to probe factors embedded in the curriculum implementation process. Oriented in a top-down approach denoting to the concept of "leading in the culture of change", Fullan's change theory specified three broad areas of factors affecting implementations labeled "characteristics of change", "local conditions", and "external factors". Each broad area of factor, as can been seen in Figure 1, is with a group of sub-factors or issues that determine how successful implementations occur and to identify factors that affect that success [4].

According to Roger's "Diffusion of Innovation Model", innovation characteristics, communication channel, time and a social system would determine whether or not an innovation survives the implementation process [5]. Fullan's change theory and Roger's diffusion theory-based concepts have been extensively applied to research on factors affecting the implementation of technology use in higher education institutions by scholars in a variety of fields, e.g. [6] [7]. Nevertheless, it has been criticized that existing implementation models may be too linear and simplistic to portray the complexity underlying intercorrelated factors affecting the implementation of education innovations [8]. Another feasible model regarding the implementation of pedagogical innovations using technology developed in 2004 synthesized from an astounding diversity of studies a set of common factors into a holistic integrated model based on which decisions concerning immediate priorities that influence the implementation could result from adequately considering all possible factors, attributes or variables extracted from literature on curriculum implementation [9]. Roles within the school, roles outside the school, organization of learning, organizational climate, staff training and development and infrastructure and resources are the five categories depicting the process of guiding and integrating an innovation into the routine practice of the adopter.

\begin{tabular}{|c|c|c|}
\hline Characteristics of Change & Local Factors & External Factors \\
\hline $\begin{array}{l}\text { - Need of change } \\
\text { - Clarity about goals and } \\
\text { needs } \\
\text { - Complexity: the extent of } \\
\text { change required to those } \\
\text { responsible for } \\
\text { implementation } \\
\text { - Quality and practicality } \\
\text { of the program }\end{array}$ & $\begin{array}{l}\text { - The school } \\
\text { district } \\
\text { - Board of } \\
\text { community } \\
\text { - Principal } \\
\text { - Teacher }\end{array}$ & $\begin{array}{l}\text { - Government and } \\
\text { other agencies }\end{array}$ \\
\hline
\end{tabular}

Figure 1. Characteristics of change local factors external factors [4]. 
To fit the overall scope of the proposed study, Fullan's three broad areas of factors [4] and the five categories contributed by Nachmias and colleagues [9] are considered relevant to the present study and serve as the basis for benchmarking a hypothetical framework on which the study rests for further investigation on factors critical to the implementation of a MICE professional English program through Delphi judgments and the AHP analysis.

\subsection{The Application of AHP to Educational Research}

Analytic Hierarchy Process (AHP), initiated by Saaty in 1971, has been widely used to deal with multi-criteria decision making in management, economics, marketing, and engineering [10]. Increasing numbers of research studies have begun to adopt AHP to assess, construct, generate, prioritize or measure competences demanded by various professions [11]-[13]. Those studies all involved the evaluation of the relative importance of attributes or criteria by experts or key stakeholders in fields under investigation. The literature contains other interesting research studies of AHP applications to education settings. The feasibility of AHP in educational research can also be found in studies on English language program planning, introductory programming course design, and so forth [14]-[16].

\section{Methodology}

\subsection{Hierarchy Model Development}

The Delphi panelists, or the hierarchy task force, consisting of 7 experts in the field of educational administration and leadership in Taiwan, were recruited in the pilot study to identify a three-level hierarchy for further AHP judgment. Panelists were asked to qualitatively examine conceptual frameworks constructed by in the literature review section [4] [9]. As a result of the expert panel discussion, three categories (dimensions) inclusive of 14 factors were selected for further AHP analysis. A summary of an integrated framework was given below in Figure 2 based on the Delphi panelists' reviews and discussions.

\subsection{AHP Instrument}

An AHP questionnaire was structured based on the AHP hierarchy before issuing to the same group of 7 experts. A total of 14 factors were identified pertaining to the three dimensions considered to be critical for program implementation. According to Saaty [10], AHP questionnaires allow participants to choose a value scaling from 1 to 9 to rate the relative priorities between several pairs of alternatives under particular criteria with respect to a specific goal. The cornerstone of AHP is the pairwise comparison procedure which helps experts independently judge the relative importance of each criterion to the goal [10]. To generate effectiveness comparisons, a detailed instruction for the Delphi penal were provided for using the 1-to-9 scale as shown in Table 1 below.

Table 1. Scale used in AHP pairwise comparisons.

\begin{tabular}{|c|c|c|}
\hline \multirow{2}{*}{ Intensity of Importance } & \multicolumn{2}{|r|}{ Scale used in AHP pairwise comparisons } \\
\hline & Definition & Explanation \\
\hline 1 & Equal importance & Two activities contribute equally to the objective \\
\hline 3 & Weak importance of one over another & Experience and judgment slightly favor one activity over another \\
\hline 5 & Essential or strong importance & Experience and judgment strongly favor one activity over another \\
\hline 7 & Very strong importance & An activity is strongly favored and its dominance demonstrated in practice \\
\hline 9 & Absolute importance & $\begin{array}{c}\text { The evidence favoring one activity over another is of the highest possible } \\
\text { order of affirmation }\end{array}$ \\
\hline $2,4,6,8$ & Intermediate values & When compromise is needed \\
\hline $\begin{array}{l}\text { Reciprocals of } \\
\text { above nonzero }\end{array}$ & $\begin{array}{r}\text { If activity } i \quad \mathrm{l} \\
\text { when compared with activity }\end{array}$ & $\begin{array}{l}\text { has one of the above nonzero numbers assigned to it } \\
\text { y } j \text {, then } j \text { has the reciprocal value when compared with } i \text {. }\end{array}$ \\
\hline
\end{tabular}




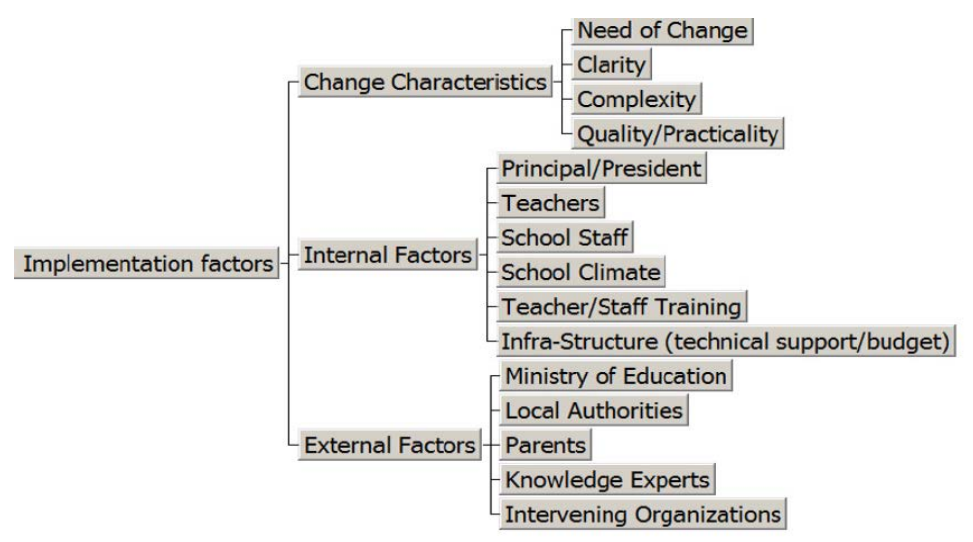

Figure 2. An AHP hierarchy pertaining to influential factors for program implementation.

\subsection{AHP Data Analysis Procedure}

This stage of the analysis was performed using Expert Choice 11.5 for dimension weights and factor ranking. The validity of the questionnaire survey result was examined based on Satty's consistency test, aiming to provide a direct measure of consistency of judgment elicited by the experts. A consistency ratio (C.R.) measures how far a decision maker's judgments are from perfect consistency. It is obtained by dividing C.I. by Random Index (R.I.).

According to Saaty [10], the 1st-order criteria matrix size in the present study is 3 , and the R.I. is 0.58 . Therefore, if the C.R. is less than 0.10 , the judgments are reasonably consistent and therefore acceptable. If the C.R. is greater than 0.10, it is suggested that the decision-makers reevaluate their judgments. It can be seen from Figure 3 below that the overall inconsistency $=0.09$ (i.e. C.I. $=0.09$ ), indicating that the present study yields an acceptable level of overall C.R. of 0.15 , which was slightly exceeded the satisfactory level of consistency. The researchers, therefore, conduct the 2nd expert panel for the purpose of qualitatively modifying the ranking result. The 7 panelists reached consensus on the final ranking of the top five factors executed by the Expert Choice without further comments.

\section{Data Analysis Result}

Figure 3 shows the priority weights among 2nd-order dimensional factors and their ranking. The result executed by Expert Choice graphed in Figure $\mathbf{4}$ shows the overall weights for the 1st-order criteria (dimensions), and local and global weights for the 2nd-order criteria (factors). "Internal Factors", has an overall weight of $62.0 \%$, plays an important role in experts' judgments of critical dimension selection. The dimension of "Change Characteristics" accounts for 29.0\%, and the dimension of "External Factors" for 8.9\%. Among the 2nd-order criteria (factors) presented in Figure 3, the top five influential factors are "Teacher/Staff Training" has the highest weight (24.0\%), followed by "Infrastructure (technical support \& budget)" (18.7\%), "Quality/Practicality" (11.2\%), "Teachers" (10.2\%) and "Principal/President" (8.4\%). The last three choices are "Complexity", "Local Authorities' and Parents'”, with weights of less than $1.5 \%$, respectively.

\section{Conclusion and Discussions}

A focus on priority factors that would facilitate or impede program implementation in a particular context seems vital to sustainability of such implementation [17]. To date, very few empirical studies on ESP program implementation have been conducted in Taiwan's tertiary settings. The present study, therefore, bears practical implementations by pointing to the importance of key stakeholders (school policy decision-makers, administrators, department heads and teachers) engaged in the implementation endeavors in providing a supportive condition to address critical success factors as predictors contributing to curriculum sustainability. They need to be aware of those highly prioritized factors and strive by every means to reduce the hindering factors and maximize the supportive ones for the intended group of implementers. Teacher/staff training, infrastructure (technical support 


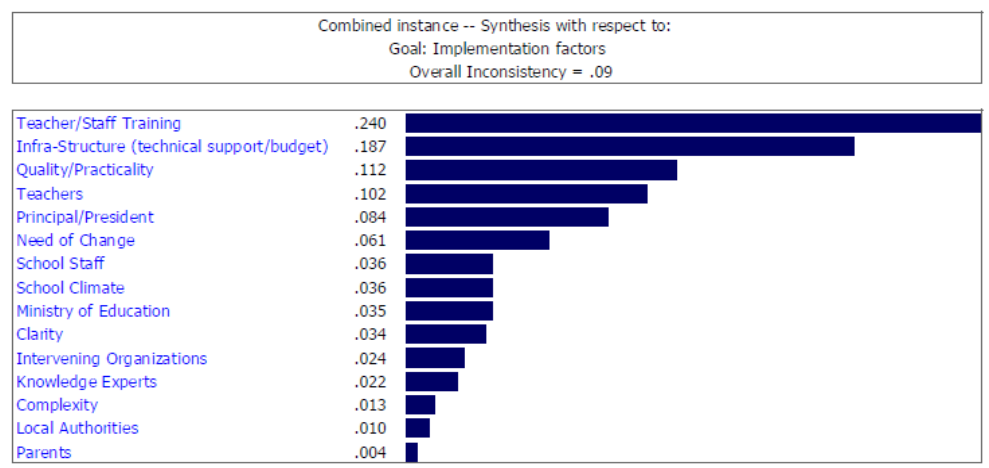

Figure 3. Overall prioritization of 2nd-order factors.

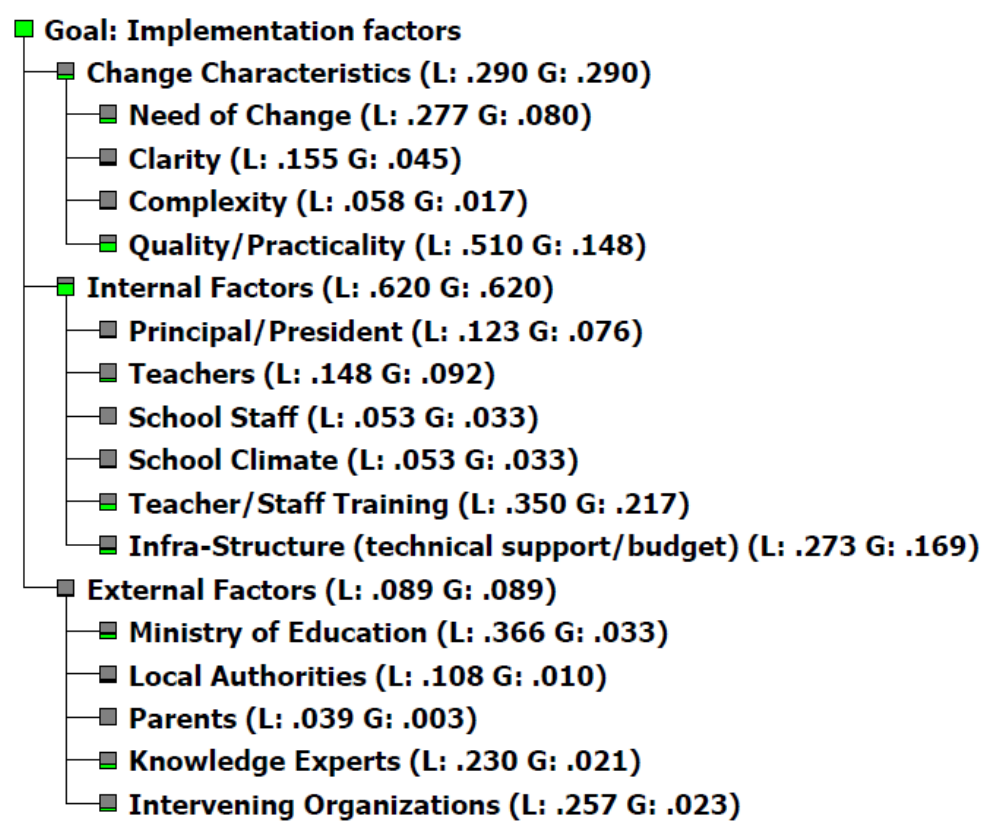

Figure 4. Local and global weights of dimensions and factors.

\& budget), quality/practicality of the innovation, teachers' attitudes, motivations and resistance towards the intended program, and school presidents' leadership were identified key factors critical to the successful implementation of the program for cultivating international MICE professionals at a tertiary setting in Taiwan.

Since successful implementations of any educational innovation relate to the dynamics of change at the school, it is suggested that future research be applied to the design of a longitudinal study to monitor and evaluate the entire implementation process of the MICE professional English program. Future studies may also expand the sample size of the proposed study by taking into account judgments from key stakeholders in similar educational institutions of similar nature and size in Taiwan. Methodologically, the proposed study attempts to make an original contribution to prioritizing critical factors for MICE professional English program implementation; the method introduced in the study will help future researchers understand how ESP programs can be implemented effectively in other settings to achieve maximum impact.

\section{Acknowledgements}

This research was funded by a research grant from the Ministry of Science and Technology (formerly known as the National Science Council) in Taiwan (NSC 102-2410-H-130 -042). 


\section{References}

[1] Hing, N., McCabe, V., Lewis, P. and Leiper, N. (1998) Hospitality Trends in the Asia-Pacific: A Discussion of Five Key Sectors. International Journal of Contemporary Hospitality Management, 10, 264-271. http://dx.doi.org/10.1108/09596119810240852

[2] UFI (2011) The Global Exhibition Industry Statistics 2011. http://www.ufi.org/Medias/pdf/thetradefairsector/2011_exhibiton_industry_statistics.pdf

[3] Tang, H.W. and Yin, M.S. (2014) Constructing a Competence Model for International Professionals in the MICE Industry: An Analytic Hierarchy Process Approach. Journal of Hospitality, Leisure, Sport \& Tourism Education, 15, 34-49. http://dx.doi.org/10.1016/j.jhlste.2014.04.001

[4] Fullan, M. (2007) The New Meaning of Educational Change. 4th Edition, Teachers College Press, New York.

[5] Rogers, E.M. (1995) Diffusion of innovation. 4th Edition, The Free Press, New York.

[6] Alias, N.A. and Zainuddin, A.M. (2005) Innovation for Better Teaching and Learning: Adopting the Learning Management System. Malaysian Online Journal of Instructional Technology, 2, 27-40.

[7] Lee, Y.H., Hsieh, Y.C. and Hsu, C.N. (2011) Adding Innovation Diffusion Theory to the Technology Acceptance Model: Supporting Employees’ Intentions to Use E-Learning Systems. Educational Technology \& Society, 14, 124137.

[8] MacVaugh, J. and Schiavone, F. (2010) Limits to the Diffusion of Innovation: A Literature Review and Integrative Model. European Journal of Innovation Management, 13, 197-221. http://dx.doi.org/10.1108/14601061011040258

[9] Nachmias, R., Mioduser, D., Cohen, A., Tubin, D. and Forkosh-Baruch, A. (2004) Factors Involved in the Implementation of Pedagogical Innovations Using Technology. Education and Information Technologies, 9, 291-308. http://dx.doi.org/10.1023/B:EAIT.0000042045.12692.49

[10] Saaty, T.L. (2006) The Analytic Network Process, Decision Making with the Analytic Network Process. International Series in Operations Research and Management Science, 95, 1-26. http://dx.doi.org/10.1007/0-387-33987-6_1

[11] Fan, C.K., Sheu, Y.K.,Wang, J.M. and Lee, Y.H. (2008) Using Analytic Hierarchy Process Method and Sensitivity Analysis to Evaluate Curriculum in Department of Risk Management and Insurance. Journal of Innovation and Management, 5, 57-178.

[12] Li, P.Y.P. and Wang, F.J. (2010) An Analysis of Essential Competencies of Hotel First Level Supervisors. International Journal of Organizational Innovation, 3, 140-161.

[13] Lin, H.Y., Lin, S.H., Chiu, C.Y., Hung, W.T. and Chen, C.Y. (2010) An AHP Approach to Industry-Oriented Management Competence Development in an Institute of Technology. World Transactions on Engineering and Technology Education, 8, 339-343.

[14] Kim, H., Han, Y., Kim, S. and Choi, M. (2005) A Curriculum Design for E-Commerce Security. Journal of Information Systems Education, 16, 55-64.

[15] Parker, K.R., Chao, J.T., Ottaway, T.A. and Chang, J. (2006) A Formal Language Selection Process for Introductory Programming Courses. Journal of Information Technology Education, 5, 133-150.

[16] Tang, H.W.V. (2011) Optimizing an Immersion ESL Curriculum Using Analytic Hierarchy Process. Evaluation and Program Planning, 34, 343-352. http://dx.doi.org/10.1016/j.evalprogplan.2011.04.002

[17] Durlak, J.A. and Dupre, E.P. (2008) Implementation Matters: A Review of Research on the Influence of Implementation on Program Outcomes and the Factors Affecting Implementation. American Journal of Community Psychology, 41, 327-350. http://dx.doi.org/10.1007/s10464-008-9165-0 